\title{
Uranium-series dating of gypsum speleothems: methodology and examples.
}

\author{
Laura Sanna ${ }^{1}$, Francisco Saez $^{2}$, Siri Simonsen ${ }^{3}$, Silviu Constantin ${ }^{1,4}$, Jose-Maria \\ Calaforra $^{5}$, Paolo Forti ${ }^{6}$ and Stein-Erik Lauritzen*1,7.
}

\begin{abstract}
:
Sanna L., Saez F., Simonsen S., Constantin S., Calaforra J.M., Forti P. and Lauritzen S.-E. 2010. Uranium-series dating of gypsum speleothems: methodology and examples. International Journal of Speleology, 39(1), 35-46. Bologna (Italy). ISSN $0392-6672$.

The analytical problems of dating gypsum speleothems with the U-series technique are reviewed. Gypsum speleothems are, in general, very low in $\mathrm{U}$ content, challenging the limits of detection methods. Various approaches to dissolving gypsum and isolation of actinides from the matrix include ion-pairing dissolution with magnesium salts and using nitric acid. The most precise dating technique is Thermal lonization Mass Spectrometry (TIMS), combined with $\mathrm{Fe}(\mathrm{OH})_{3}$ scavenging and anionic exchange chromatography. Less satisfactory, but much quicker, is direct retention of actinides from $\mathrm{HNO}_{3}$ by means of TRU resin and MC-ICP-MS detection. We have tested these methods on gypsum speleothems from the Sorbas karst in Spain and from the Naica caves in Mexico.
\end{abstract}

Keywords: Uranium series dating, gypsum, cave, methodology

Received 10 December 2009; Revised 19 December 2009; Accepted 13 January 2010

\section{INTRODUCTION}

Uranium-series dating of speleothems is standard procedure in speleological science and in palaeoclimatic research (Ford \& Williams, 2007; Ivanovich \& Harmon, 1982). Carbonate speleothems are widespread in space and time and have generally enough uranium to allow determination of isotopic ratios of the element itself and its radiogenic daughters. In principle, all spelean secondary minerals can be used for dating, provided that their initial isotopic composition is known and that they contain enough actinides for reliable determination. In spite of this, most of the attention has been on calcite speleothems, for which there are numerous standard procedures available.

Gypsum speleothems are a rarely used, if they can

1 GEO, Department of Earth Sciences, Bergen University.

Allegaten 41, N-5007, Bergen, Norway.

2 c/Actor Paco Rabal, 1-1E 30820 Alcantarilla, Murcia, Spain.

3 Department of Geoscience, University of Oslo, P.O.Box 1047

Blindern 0316 Oslo, Norway.

4 "Emil Racovita" Institute of Speleology. Str. Frumoasa 31, 010986 Bucuresti 12, Romania.

5 Department of Hydrogeology, University of Almeria, Almeria, Spain. 6 Earth and Geological Evironmental Sciences, University of Bologna, Via Zamboni 67, 40126 Bologna, Italy.

7 Department of Plant and Environmental Sciences, P.O.Box 5003

N-1432 Ås, Norway.

* corresponding author: stein.lauritzen@geo.uib.no (Quaternary

Uranium-series Dating Laboratory, Bergen) be successfully dated, a potentially excellent source of palaeoenviromental and geomorphic information. For instance, many gypsum karsts, like Sorbas in southern Spain (Calaforra, 1998), the Gypsum area near Bologna in Italy (Forti \& Rossi, 2003) and the New Mexico gypsum karst (Calaforra \& Forti, 1994) contain gypsum speleothems (Klimchouk et al., 1997). There is also a great variability in gypsum speleothems with regards to their size, external shape, internal structure and development. Davis (2000) reports from Lechuguilla Cave (New Mexico, USA) gypsum stalactites, columns, hairs, "Candelieres" (up to $6 \mathrm{~m}$ long), flowers and needles (>1 $\mathrm{m}$ long). Korshunov and Shavrina (1998) focus on cryogenic gypsum speleothems and describe gypsum powder (formed after ice sublimation), gypsum yozh (with spherical, hemispherical, flat or amorphous shape, with development closely related to clay deposits), and spherical porous yozh with an unclear genesis. Gypsum trays have been reported by Calaforra \& Forti (1994) and Doran \& Hill (1998) as clusters of popcorn or grape coralloids ending in a flat surface. Gypsum nests has been described by Maltsev (1997) at Geophysicheskaya Cave, Turkmenistan, as a funnel-shaped mass of thousands of oriented gypsum needles with a hollow interior. Gypsum crusts in lava tubes have recently been dated by U-series technique (Dillon, 2009). Also, northern caves, even in relatively cold and wet regions like north Norway, contain evaporitic gypsum crusts (Lauritzen, 2002; Onac \& Lauritzen, 1995). It is evident that dating of these various cave minerals can give valuable information 
for understanding their formation and of the environment they were formed in. The purpose of this paper is to give a review of various methods that are practically useful for bringing gypsum into solution in manageable volumes, and of isolation and separation techniques for actinides and their measurement by radiometric and mass spectrometric techniques.

\section{PRACTICAL ASPECTS OF U- SERIES DATING}

Detection of actinides for U-series dating is at present based on wet chemistry where the sample is decomposed in sufficient amount to yield detectable levels of the analyte. In general, the amount of sample required, the choice of decomposition method and the volume and further handling of the resulting solution depend on the uranium content and mineralogy of the sample (Bock, 1979; Novozamsky et al., 1995).

For dating of carbonate speleothems, the mineral is brought into solution by means of acids $\left(\mathrm{HCl}, \mathrm{HNO}_{3}\right)$, which means that "solubility" can theoretically attain 10 - 15 moles $\mathrm{L}^{-1}$, so that large amounts of sample in any case can be dissolved in manageable volumes of liquid. The amount of sample required depends on its $U$ content and on the technique used. Modern techniques have extremely low detection limits compared to the classic $\alpha$-particle counting. As spelean calcite commonly contains $0.1-1$ ppm U, $5-20 \mathrm{~g}$ samples were prepared for $\alpha$-particle counting, $0.5-2$ $\mathrm{g}$ for TIMS (Thermal Ionization Mass Spectrometry), and 0.05 - $0.2 \mathrm{~g}$ for ICP-MS (Ionization Coupled Plasma - Mass Spectrometry) analyses. With the latter two techniques, sample size and reagent volumes are no problem when it comes to carbonates. Isolation of actinides from the concentrated $\left[\mathrm{Ca}^{2+}\right]$ solutions involves destruction of potential organic chelators either by dry ignition $\left(600^{\circ} \mathrm{C}\right.$, prior to dissolution) or wet oxidation with $\mathrm{HClO}_{4}$ or $\mathrm{H}_{2} \mathrm{O}_{2}$, followed by ferric hydroxide scavenging. Actinides are then separated from $\mathrm{Fe}^{3+}$ and each other by ion exchange before determination. However, gypsum speleothems poses additional challenges rooted in their solubility and $U$ content. First, in gypsum speleothems, the routinely low $U$ content makes that sample size vs. volume of solute required, which are manageable for carbonates, become cumbersome. Second, the isolation and separation of actinides considering the large volumes of solute required may pose additional problems. In the U-series dating laboratory in Bergen we have tested various approaches to these issues.

\section{The solubility of gypsum in water}

When it comes to actinide extraction from gypsum $\left(\mathrm{CaSO}_{4} \cdot 2 \mathrm{H}_{2} \mathrm{O}\right)$ speleothems, a problem of its limited solubility arises for two reasons. First, gypsum speleothems often have very low uranium content, which is probably caused by the correspondingly low ion pairing affinity between $\mathrm{UO}_{2}{ }^{2+}$ and $\mathrm{SO}_{4}{ }^{2-}$, causing $\mathrm{UO}_{2}{ }^{2+}$ to stay in solution rather than being adsorbed on growing gypsum surfaces. Typically, gypsum crystals, like those in the Naica caves, contain $U$ at the $\mathrm{ppb}\left(10^{-9}\right)$ level. Second, the solubility of gypsum in water is limited to $2.4 \mathrm{~g} \mathrm{~L}^{-1}$ (CRC Handbook of
Chemistry and Physics, 1970) and has a maximum at about $+40{ }^{\circ} \mathrm{C}$ (Figure 1). In order to get sufficient intensity of the relevant atomic masses, like ${ }^{230} \mathrm{Th}$, - the isotope which measures the actual age and is often the minimum factor - gypsum amounts of up to $10 \mathrm{~g}$ or more must be dissolved. For pure water, this would require some $4.5-5 \mathrm{~L}$ in order to bring it into complete solution. For a TIMS sample, which is generally larger, and in particular, for $\alpha$-particle counting technique, the resulting volumes would not be practically manageable.

\section{Enhanced gypsum solubility by ion pairing}

In general, gypsum solubility increases with solute content (e.g. brines) (Klimchouk, 2000). The effect is largely governed by ion pairing of foreign cations and anions with $\mathrm{SO}_{4}{ }^{2-}$ and $\mathrm{Ca}^{2+}$, respectively. This lowers the activity of these ions so that more gypsum can dissolve. The effect is formidable, in particular with magnesium chloride and nitrate (Figure 1). For instance, in a 2 mole $\mathrm{L}^{-1}$ solution of $\mathrm{Mg}\left(\mathrm{NO}_{3}\right)_{2}$, the solubility of gypsum is raised from $2.4 \mathrm{~g} \mathrm{~L}^{-1}$ to $14 \mathrm{~g} \mathrm{~L}^{-1}$, an increase of $580 \%$. This means that $10 \mathrm{~g}$ gypsum can dissolve in a volume of $720 \mathrm{~mL}$. With the addition of large amounts of salts to the sample, there is a danger of contamination, so that pro analysi or purer qualities (Suprapur ${ }^{\circledR}$ ) must in any case be precleaned for actinides by adjusting $\mathrm{pH}$ and using an appropriate ion exchanger, either in column or batch mode.

\section{Yield experiments in gypsum dissolution}

In a study of gypsum balls from Sorbas caves (southern Spain), carried out in 1999-2000 at Bergen University, we tested the addition of $\mathrm{MgCl}_{2}$ on gypsum solubility (Figure 2). A practical optimum was found using $50 \mathrm{~g} \mathrm{MgCl}_{2} \cdot 6 \mathrm{H}_{2} \mathrm{O}$ in $450 \mathrm{~mL} \mathrm{H}_{2} \mathrm{O}\left(0.55 \mathrm{~mol} \mathrm{~L}^{-1}\right)$, which could dissolve $7 \mathrm{~g}$ gypsum speleothem. Beyond this ratio, increasing the amount of $\mathrm{MgCl}_{2} \cdot 6 \mathrm{H}_{2} \mathrm{O}$ would lead to the precipitation of epsomite $\left(\mathrm{MgSO}_{4} \cdot 7 \mathrm{H}_{2} \mathrm{O}\right)$. In a neutral or only slightly acidic solution, actinides - and Th in particular - would plate out on insoluble particles and on the walls of glassware. In order to retain $\mathrm{Th}$ in solution, $\mathrm{pH}$ needs to be below $\sim 1$. Some gypsum speleothems contain detrital components, like air-borne dust or floodwater silt, that are not relevant to the age of the speleothem formation (often much older). Strong acid could in principle attack these particles, which are most likely carbonate and clay, and thereby contaminate the digest with non-authigenic $U$ and Th. This is linked to the wellestablished allogenic ${ }^{230} \mathrm{Th}$ contamination problem of so-called "dirty" calcites (Przbylowicz et al., 1991; Schwarcz, 1980; Schwarcz \& Latham, 1989). It is therefore necessary to find a compromise between risking authigenic ${ }^{230} \mathrm{Th}$ to plate out (at high $\mathrm{pH}$ ) and contamination of non-authigenic ${ }^{230} \mathrm{Th}$ to dissolve from detrital surfaces (at low $\mathrm{pH}$ ). Hence, a series of tests was performed on the $\mathrm{MgCl}_{2}$ procedure to investigate the effects of $\mathrm{pH}$ on the resulting ages and on the chemical yield of $U$ and Th through the procedure. At the time when these experiments were done, we 

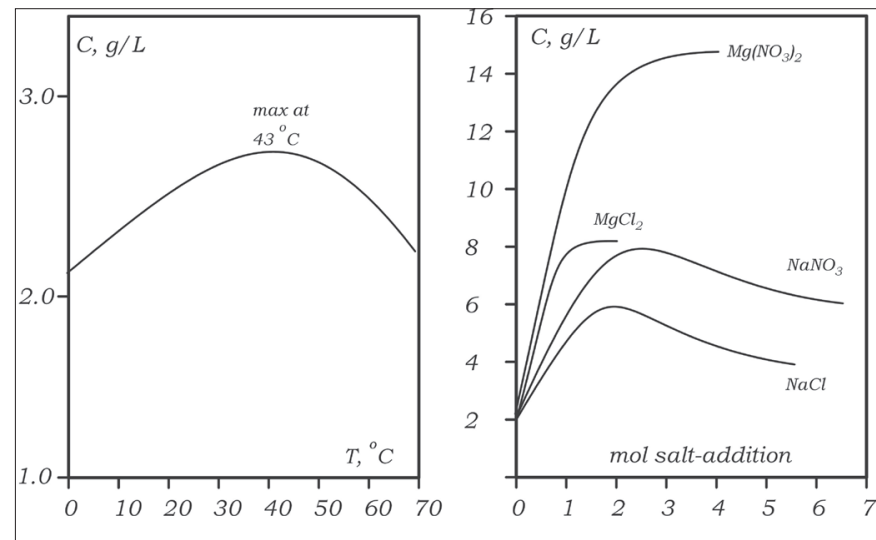

Fig. 1. Solubility of gypsum. Left: Gypsum solubility in pure water as a function of temperature. Right: Gypsum solubility as a function of concentration of other salts. Magnesium chloride and nitrate have a very strong effect on gypsum solubility. (Modified after Klimchouk, 2000)

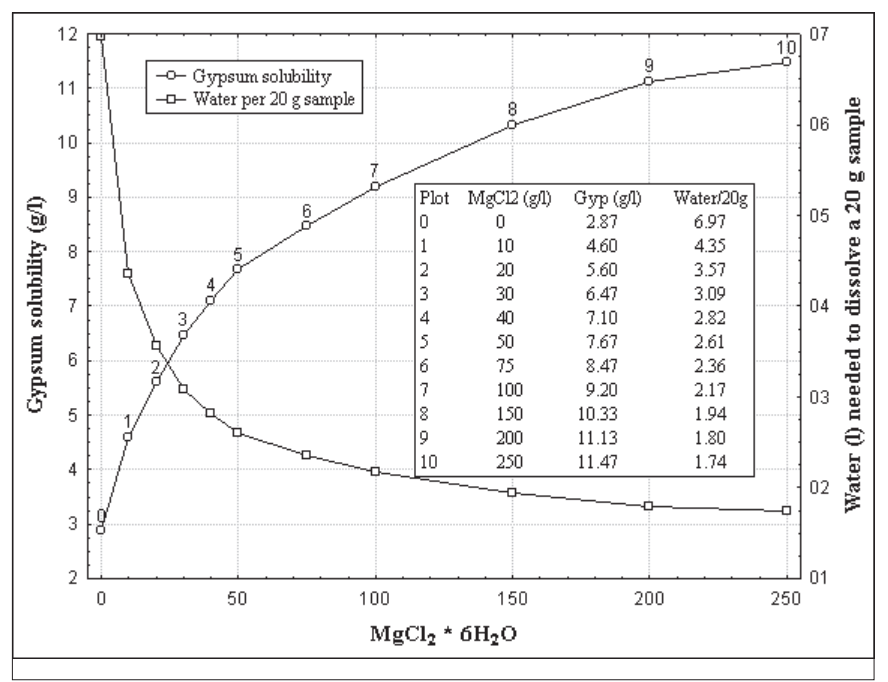

Fig. 2. Solubility of gypsum in solution with different concentrations of $\mathrm{MgCl}_{2} \cdot 6 \mathrm{H}_{2} \mathrm{O}$. Further experiments with speleothems used $50 \mathrm{~g}$ of $\mathrm{MgCl}_{2} \cdot 6 \mathrm{H}_{2} \mathrm{O}$ per $7 \mathrm{~g}$ of gypsum sample.

found it convenient to assess chemical yields by using $\alpha$-particle counting which measures the total recovery from the chemistry. Two different speleothem samples (from Sorbas) having ages of approximately 10 and 20 kyr respectively, were chosen for testing. They were mechanically cleaned, and each was crushed to a fine powder and homogenized. Two different protocols were followed (Figure 3): in procedure A, aliquots of the powdered samples were dissolved in $0.55 \mathrm{M} \mathrm{MgCl}_{2}$ to which $\mathrm{HCl}$ had been added to $\mathrm{pH}<1$, and then filtered. In procedure $B$, acidification was done after dissolution and filtration. Spike $\left({ }^{228} \mathrm{Th} /{ }^{232} \mathrm{U}\right)$ was added to the solution during dissolution. Chemical isolation followed the normal protocol for $\alpha$-particle counting (Gascoyne, 1980), where actinides were scavenged on $\mathrm{Fe}(\mathrm{OH})_{3}, \mathrm{Fe}^{3+}$ removed by ether extraction, then $\mathrm{U}$ and Th were separated and purified by anion exchange chromatography. $\mathrm{U}$ and Th were electroplated on steel disks and counted separately. Further experiments tried acidification to $\mathrm{pH}=1.5$ and $\mathrm{pH}=2.0$. The chemical yields from these experiments are shown in Figure 4.

$\mathrm{U}$ yields are generally higher than Th yields, as is common in all preparation procedures. Both $U$ and Th yields were not significantly different from average yields of more than 3,000 carbonate analyses in this laboratory; they are always variable due to sample and operator variability. There was, however, a significant effect on Th yields, where acidification after filtration gave more variable and often quite low yields. Using $\mathrm{HCl}$ to lower the $\mathrm{pH}$ to 1.5 during gypsum dissolution gave the most consistent results and is therefore the preferred approach (Figure 4).

The low chemical yields also affect the resulting ages. Due to lower yields, counting statistics are worse, giving larger errors (Figure 5). Acidification prior to, or after, filtration did not change the radiometric ages of each sample, but dates become more precise with high yields. Due to this effect, the two samples could only be chronologically distinguished when the samples were dissolved at $\mathrm{pH}=1.5$. A similar effect was found when dating a gypsum ball from Sorbas in southern Spain (Figure 6). The ball is some $10 \mathrm{~cm}$ in diameter and consists of alternating pure white and detrital (grey) bands due to episodes of flooding or aeolian dust being adsorbed onto the speleothem. Growth bands imply that the sample grew radially (Figure 6c). Two very large subsamples had to be taken for accomodating the low sensitivity of alpha dating, yielding overlapping ages, but with inverted stratigraphic distribution (Figure 7). Re-sampling of the other half of the gypsum ball with much smaller subsamples and TIMS dating (see below) yielded much more precise dates in correct stratigraphic order (Figure 7). This example also demonstrates the need for repeated dating along sequences with a precise technique so that chronological trends can be tested; single dates can be deviant for various reasons of random subsample properties and operator skill.

\section{Application to TIMS techniques}

When we adapted this technique for application to TIMS, we have tested two different dissolution protocols: (1) using $\mathrm{MgCl}_{2} \cdot 6 \mathrm{H}_{2} \mathrm{O}$ (16 g was required to dissolve $\sim 2 \mathrm{~g}$ of gypsum in $200 \mathrm{~mL} \mathrm{H}_{2} \mathrm{O}$ ) and (2) using $2 \mathrm{M} \mathrm{Mg}\left(\mathrm{NO}_{3}\right)_{2}$ at $\mathrm{pH} 1.5$ (which has about the double dissolution capacity for gypsum than $0.55 \mathrm{M}$ $\left.\mathrm{MgCl}_{2}\right)$. In both cases the samples were spiked $\left({ }^{229} \mathrm{Th}\right.$, ${ }^{233} \mathrm{U}$ and ${ }^{236} \mathrm{U}$ ) and acidified by addition of a few drops of Suprapur $\mathrm{HNO}_{3}$. The dissolution took place at a controlled temperature of $25^{\circ} \mathrm{C}$. Further purification involved standard procedures (Lauritzen \& Lundberg, 1999) of $\mathrm{Fe}(\mathrm{OH})_{3}$ scavenging, followed by the separation of $\mathrm{Fe}^{3+}$ by ion exchange (nitrate eluant). Actinides were further separated on anion exchange columns in $\mathrm{HCl}$ and $\mathrm{HBr}$ media before being dissolved in $\mathrm{H}_{3} \mathrm{PO}_{4}$ or $\mathrm{HNO}_{3}$ and loaded on zone-refined Re filaments prior to measurements.

\section{TIMS detection}

TIMS measurements were done on a Finnigan MAT 262 RPQ instrument with the ion counter in dynamic mode, at the Department of Earth Science, Bergen University. We have tried several methods of ionization. U can be run as a metal without addition or with graphite on the filament, or as oxide from a silica bed. Th is always run as a metal from a graphite 


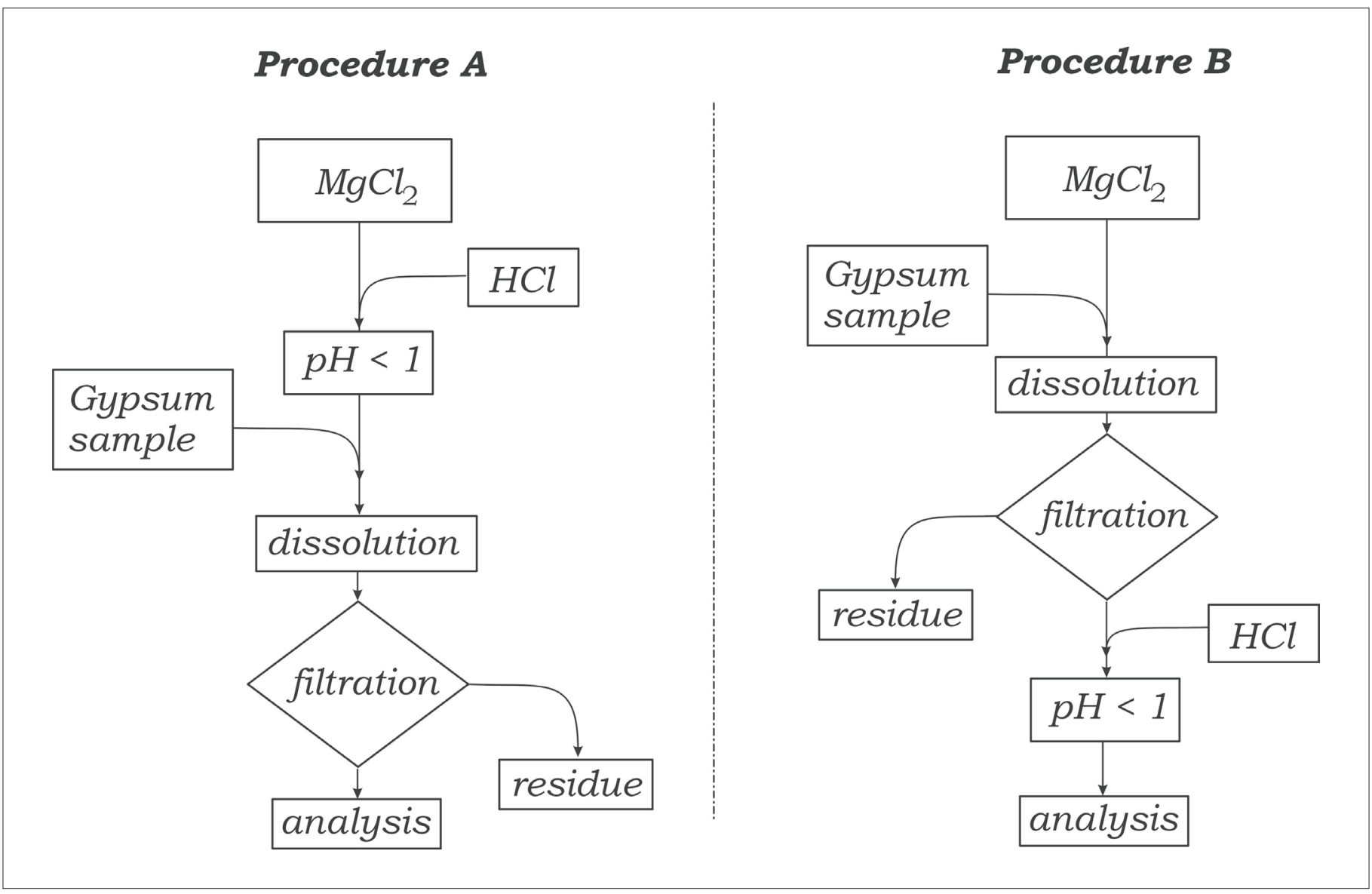

Fig. 3. Two different laboratory procedures tested to optimize the dissolution process for gypsum samples. They differ in the moment when conc. $\mathrm{HCl}$ is added to the solution.

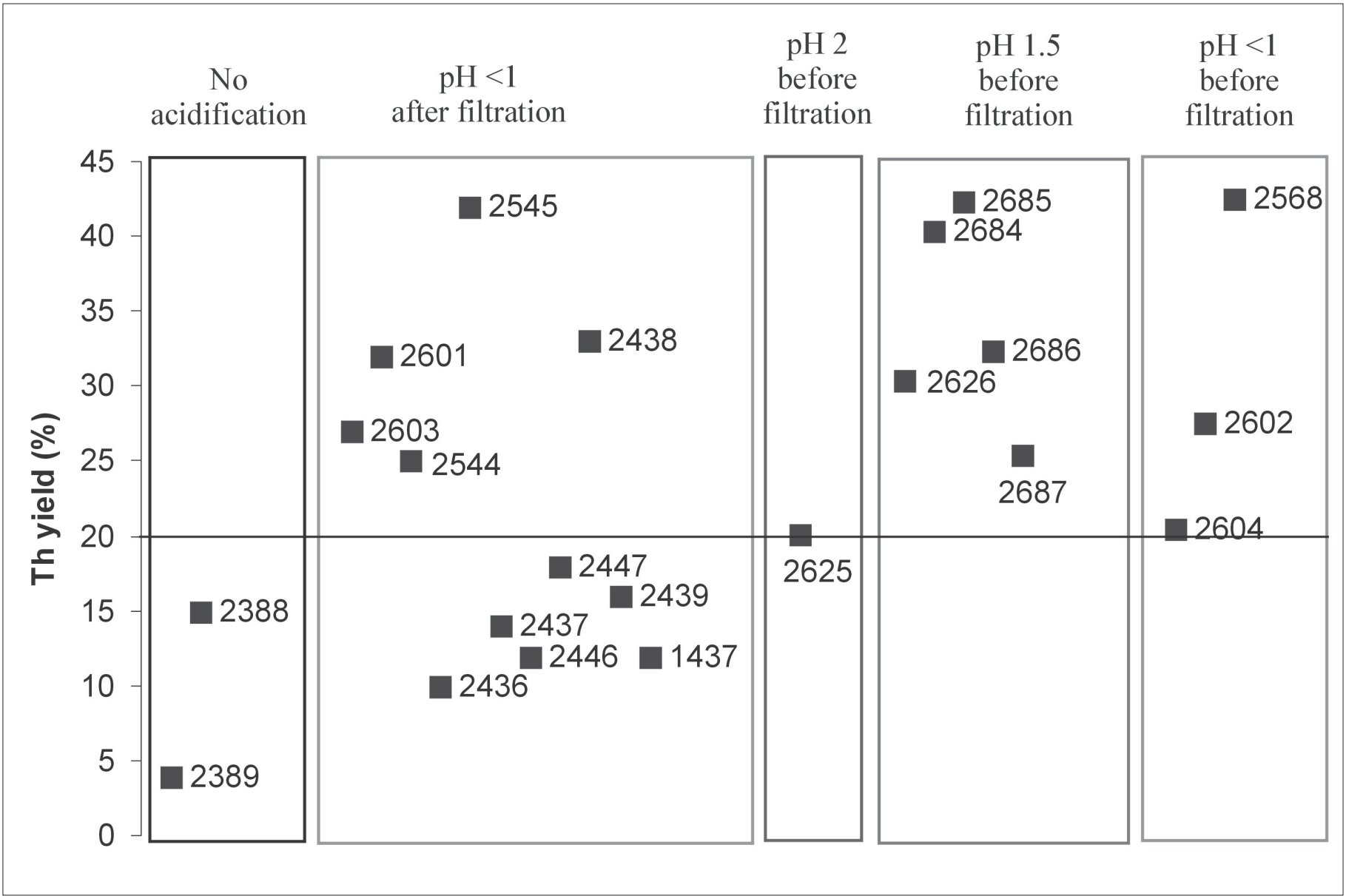

Fig. 4. Effect of different chemical situations on the Th yields. See text for discussion. Numbers refer to the Bergen Quaternary U-series lab's alpha counting journal. 


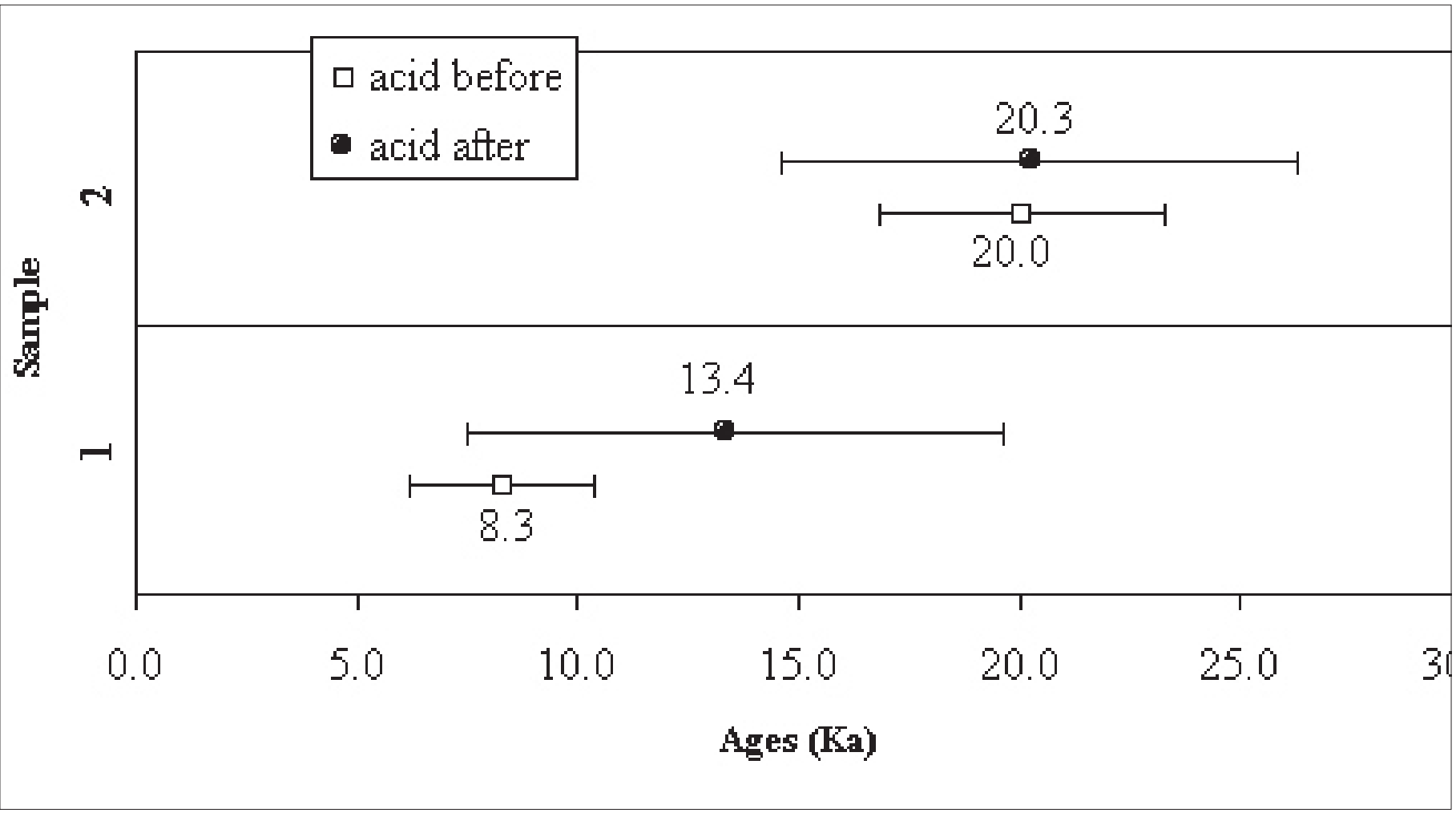

Fig. 5. Comparison of the ages obtained for two different gypsum samples (1 and 2) and two acid treatments (before and after filtering), i.e. four age determinations. When acid is added after dissolving, the errors become so big that the ages are not statistically different; but when acid is added before dissolving, the errors are smaller and the ages can be distinguished.

bed due to the extremely low volatility of its oxide. $\mathrm{U}$ was run at $1650-1775^{\circ} \mathrm{C}$; Th at $1750-1850{ }^{\circ} \mathrm{C}$ in separate runs. Mass abundances of ${ }^{236} \mathrm{U},{ }^{235} \mathrm{U},{ }^{234} \mathrm{U}$, ${ }^{233} \mathrm{U},{ }^{229} \mathrm{Th},{ }^{230} \mathrm{Th},{ }^{232} \mathrm{Th}$ were measured and converted to mass ratios. The first protocol worked satisfactorily on one Naica sample with about $4 \mathrm{ppb} \mathrm{U}$ (Lauritzen et al., 2008) with reproducibilities of $0.26 \%$ for ${ }^{234} \mathrm{U} /{ }^{238} \mathrm{U}$ and $1.62 \%$ for ${ }^{230} \mathrm{Th} /{ }^{234} \mathrm{U}(2 \sigma)$. The second protocol was successfully tested for the outer part of the gypsum crystal from Espadas Cave (Table 1), with $\sim 0.2 \mathrm{ppm}$ ${ }^{238} \mathrm{U}$. In this case the reproducibility was $\sim 0.2 \%$ for ${ }^{234} \mathrm{U} /{ }^{238} \mathrm{U}$ and $1.2 \%$ for ${ }^{230} \mathrm{Th} /{ }^{234} \mathrm{U}(2 \sigma)$. Blank tests were done to check for contamination on both $\mathrm{MgCl}_{2}$ and $\mathrm{Mg}\left(\mathrm{NO}_{3}\right)_{2}$ and they showed no ${ }^{230} \mathrm{Th}$. However, considering the very low $U$ concentrations of gypsum samples, blank tests must be routinely done.

\section{Application to ICP-MS techniques}

ICP-MS has an even lower detection limit than TIMS and, in order to minimize contamination from reagents, we have simplified the procedures further. First, introduction of new, actinide-specific resins (Peterson et al., 2007; Yang, 2009), like the Eichrom TRU resin, simplify the chemical workup procedure. The TRU resin contains a phosphate/phosphinebased liquid ion exchanger supported on an inert substrate (Amberlite XAD-7). Actinides are selectively retained directly from $1 \mathrm{M} \mathrm{HNO}_{3}$. Matrix ions $\left(\mathrm{SO}_{4}{ }^{2-}\right.$ and $\mathrm{Ca}^{2+}$ ) can then be washed out with $1 \mathrm{M}^{\mathrm{HNO}_{3}}$, followed by conversion of the eluant from a nitrate to a chloride base and subsequent elution of actinides by dilute $\mathrm{HCl} / \mathrm{HF}$. This procedure is recommended by Hellstrom (2003) and we have adapted it from him. In order to avoid both the scavenger step and addition of large amounts of magnesium salts, we tested the solubility of gypsum directly in $1 \mathrm{M}^{\mathrm{HNO}} \mathrm{H}_{3}$ and found that up to $10 \mathrm{~g}$ gypsum can be dissolved in $600 \mathrm{~mL}$ acid. After spiking and equilibrisation, the actinides can be retained on a small column. The only drawback is the relatively large volume that needs to be passed through the column, which is a time-consuming process. (Also, we do not know if the retention is optimal with such large amount of eluant). After washing and elution, the solution was dried down with $\mathrm{HNO}_{3}$ and then dissolved in $2 \% \mathrm{HNO}_{3}$ for analysis.

\section{ICP-MS detection}

Isotopic measurements were performed on a $\mathrm{Nu}$ Plasma HR multicollector ICP-MS with a U-Pb collector block at the Department of Geology, University of Oslo. Analyses were done in dry plasma using a DSN100 desolvating nebuliser with a sample uptake rate of $0.1 \mathrm{~mL} / \mathrm{min}$. Uranium and thorium were dissolved in $2 \% \mathrm{v} / \mathrm{v} \mathrm{HNO}_{3}$ prior to analysis.

The mixed uranium and thorium solution was analysed in two separate procedures. First, Uranium isotopes with mass 236, 235, 234 were determined in ion counters and Thorium with mass 232 in a Faraday cup. The second procedure measures Thorium mass 229 and 230 in an ion counter. Tailing from 238 and 232 was corrected by measuring half masses and using an exponential interpolation. Fractionation of the instrument has been determined on a daily basis by analysing mass 235 and 238 of a natural uranium solution in Faraday cups using 238/235= 137.88. Early attempts on measuring fractionation by analysing ${ }^{236} \mathrm{U} /{ }^{233} \mathrm{U}$ were abandoned due to problems 
A

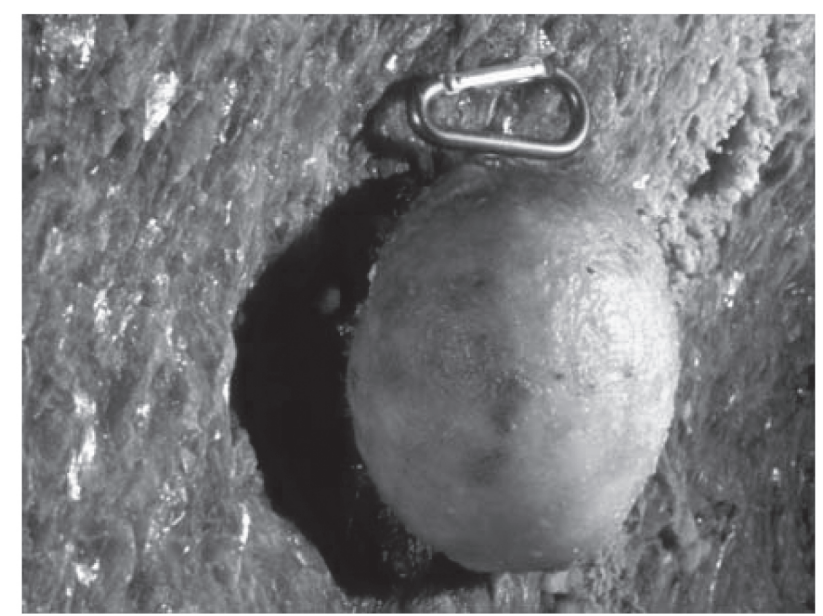

B

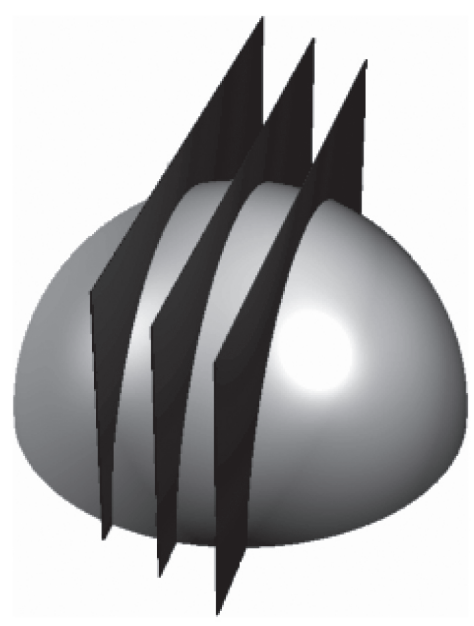

C
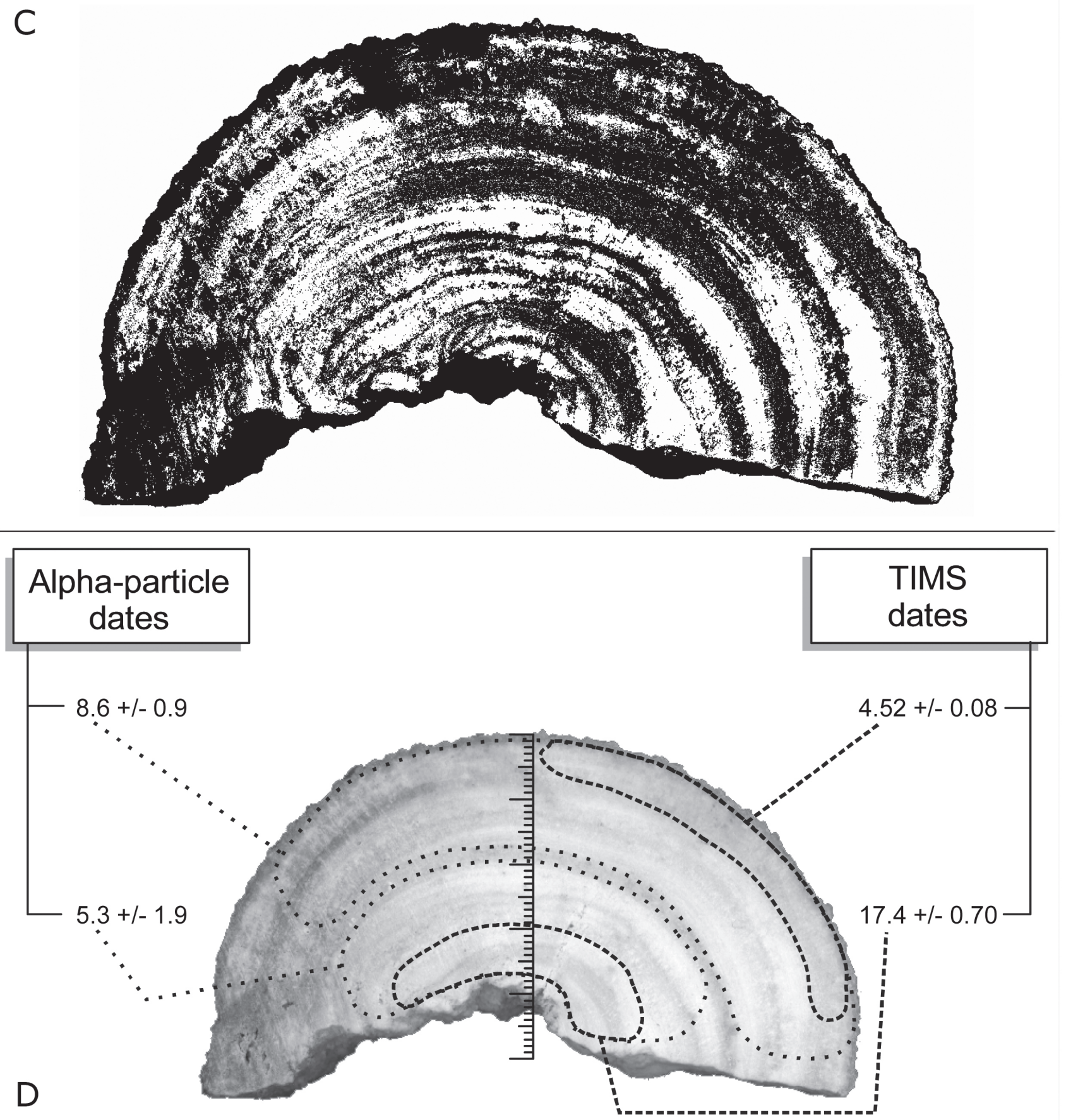

Fig. 6. Gypsum ball from the Sorbas karst, southern Spain. A) photo of in situ ball on the cave wall. B) section done for analysis. C) Structure of layers inside the speleothem. Dark bands contain dust, while lighter ones are made of more pure gypsum. D) Ages obtained with alpha particle spectrometry and mass spectrometry for the same speleothem. 


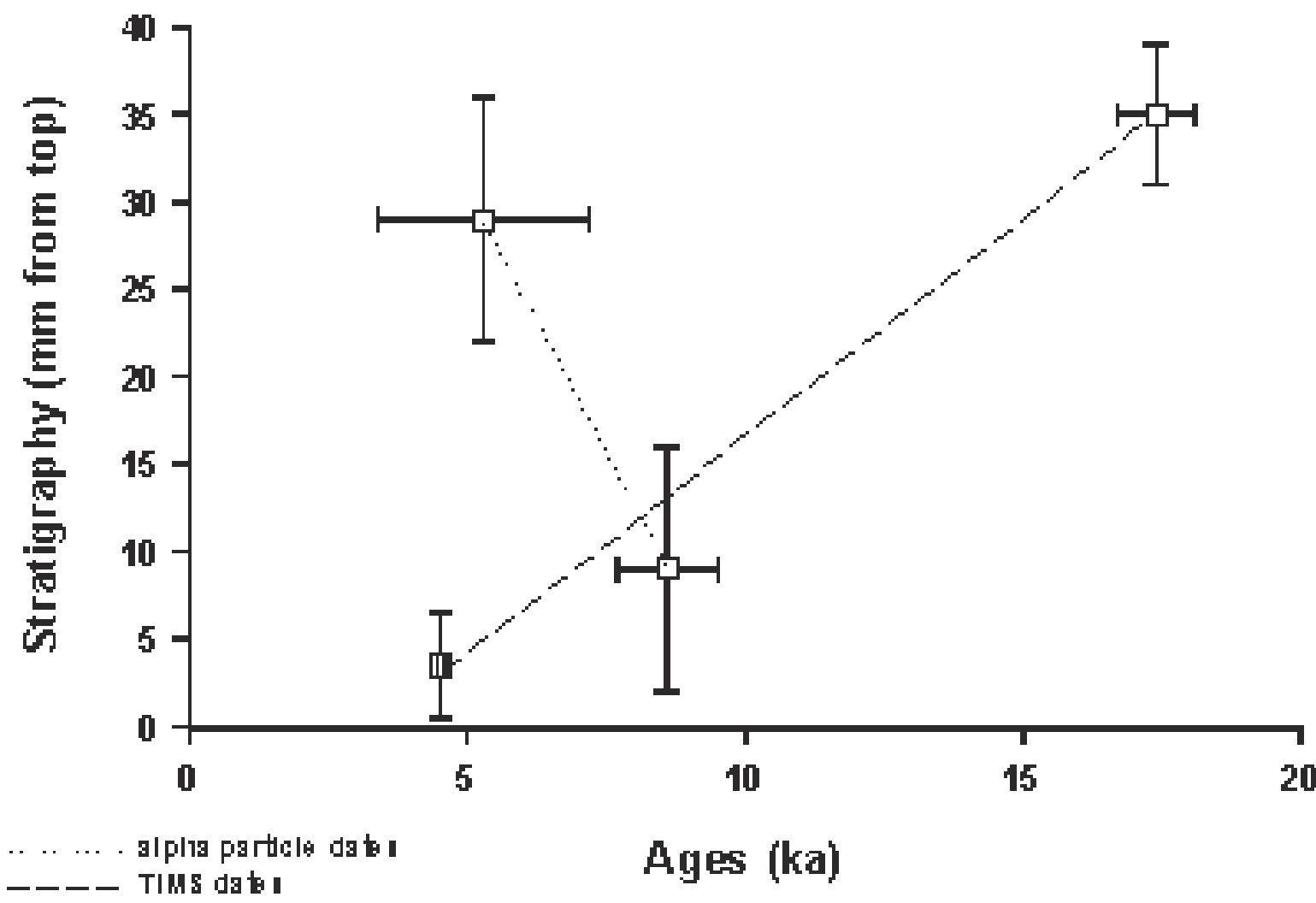

Fig. 7. Gypsum ball from Sorbas (see figure 6). Stratigraphy vs. age for the samples obtained. $\sigma$-particle dates yield large errors $(1 \sigma)$ and overlapping ages that also appear inverted with stratigraphy. TIMS dates are, in spite of low $U$ content, much more precise $(2 \sigma)$ and in correct stratigraphic order.

with hydride formation from ${ }^{232} \mathrm{Th}$. The reproducibility of each measured ${ }^{234} \mathrm{U} /{ }^{238} \mathrm{U}$ ratio was $0.11 \%(2 \sigma)$.

Repeated analyses of BR5 (a high Uranium speleothem powder standard used in Bergen) gave an age of $125.862 \pm 1.546 \mathrm{kyr}(\mathrm{n}=12)$, with a reproducibility of measured ${ }^{234} \mathrm{U} /{ }^{238} \mathrm{U}$ ratio of $0.59 \%$ $(2 \sigma)$. Age determinations were based on measured atomic mass ratios of ${ }^{235} \mathrm{U} /{ }^{236} \mathrm{U},{ }^{235} \mathrm{U} /{ }^{234} \mathrm{U},{ }^{236} \mathrm{U} /{ }^{234} \mathrm{U}$, ${ }^{232} \mathrm{Th} /{ }^{229} \mathrm{Th}$; and ${ }^{229} \mathrm{Th} /{ }^{230} \mathrm{Th}$. Data reduction, error optimization and propagation were done using tailored software (Lauritzen and Lundberg, 1997) which has been rewritten for the Windows environment.

\section{Example analyses on Naica gypsum crystals \\ Sample description}

The Naica mine (Chihuahua, Mexico) is well-known for the dimension and purity of gypsum crystals that fill several natural cavities cut by its galleries (Foshag, 1927). The Naica caves were discovered at different levels inside the mine and observations suggest that these crystals grew in three different environments (deep phreatic, epiphreatic and sub-aerial) until the caves were dewatered in 1985 (Forti et al., 2009a). We have analysed one selenite sample from each of the three most important caves (Figure 8): Cueva de las Espadas (Cave of the Swords at the $-120 \mathrm{~m}$ level), Ojo

Table 1. ICP-MS and TIMS Uranium series dates of Naica cave crystals.

\begin{tabular}{|c|c|c|c|c|c|c|c|c|c|c|c|c|c|}
\hline $\begin{array}{l}\text { Ulab } \\
\text { No }\end{array}$ & $\begin{array}{c}\text { ID } \\
\text { sample }\end{array}$ & Cave & Method & $\underset{(p p m)}{U}$ & ${ }^{234} \mathrm{U} /{ }^{238} \mathrm{U}$ & ${ }^{230} \mathrm{Th} /{ }^{234} \mathrm{U}$ & ${ }^{230} \mathrm{Th} /{ }^{232} \mathrm{Th}$ & $\begin{array}{c}\text { Age, } \\
\text { kyr }\end{array}$ & $2 \sigma+$ & $2 \sigma-$ & $\begin{array}{l}\text { Corr. } \\
\text { age }^{1}\end{array}$ & $2 \sigma+$ & $2 \sigma-$ \\
\hline 850 & N01-1 & Ojo & ICPMS & 0.0010 & $\begin{array}{l}1.05741 \\
\pm 0.0129\end{array}$ & $\begin{array}{c}0.87149 \pm \\
0.0133\end{array}$ & $7 \pm 0.49$ & 213.700 & 12.53 & 11.03 & 191.018 & 13.75 & 12.50 \\
\hline $853 b$ & N07-10 & Cristales & ICPMS & 0.0002 & $\begin{array}{r}1.33974 \\
\pm 0.0933\end{array}$ & $\begin{array}{c}0.82823 \pm \\
0.1406\end{array}$ & $12 \pm 1.85$ & 168.838 & 101.14 & 51.80 & 158.526 & 101.64 & 51.96 \\
\hline 858 & ESP1-1 & Espadas & ICPMS & 0.0460 & $\begin{array}{r}2.36105 \\
\pm 0.0109\end{array}$ & $\begin{array}{c}0.44666 \pm \\
0.0773\end{array}$ & $19 \pm 18.62$ & 60.457 & 0.07 & 0.07 & 57.010 & 1.77 & 1.77 \\
\hline $863 b$ & ESP1-2 & Espadas & ICPMS & 0.1625 & $\begin{array}{r}2.97474 \\
\pm 0.0294\end{array}$ & $\begin{array}{c}0.13186 \pm \\
0.0334\end{array}$ & $29 \pm 7.43$ & 15.209 & 4.14 & 4.02 & 14.491 & 4.15 & 4.03 \\
\hline 796 & ESP-surf & Espadas & TIMS & 0.2000 & $\begin{array}{c}3.42787 \\
\pm \\
0.00671\end{array}$ & $\begin{array}{c}0.24131 \pm \\
0.00289\end{array}$ & $949 \pm 20$ & 7.874 & 0.04 & 0.04 & 7.863 & 0.04 & 0.04 \\
\hline 788 & $\mathrm{~N} 1$ & Cristales & TIMS & 0.0038 & $\begin{array}{c}0.76927 \\
\pm 0.0020\end{array}$ & $\begin{array}{c}0.30282 \pm \\
0.0049\end{array}$ & $10 \pm 0.17$ & 40.071 & 0.82 & 0.81 & 34.544 & 0.82 & 0.81 \\
\hline
\end{tabular}

${ }^{1}$ Correction for detrital ${ }^{230} \mathrm{Th}$ contamination, assuming "world mean" initial ${ }^{230} \mathrm{Th} /{ }^{232} \mathrm{Th}$ of 1.5 , (Richards \& Dorale, 2003). 

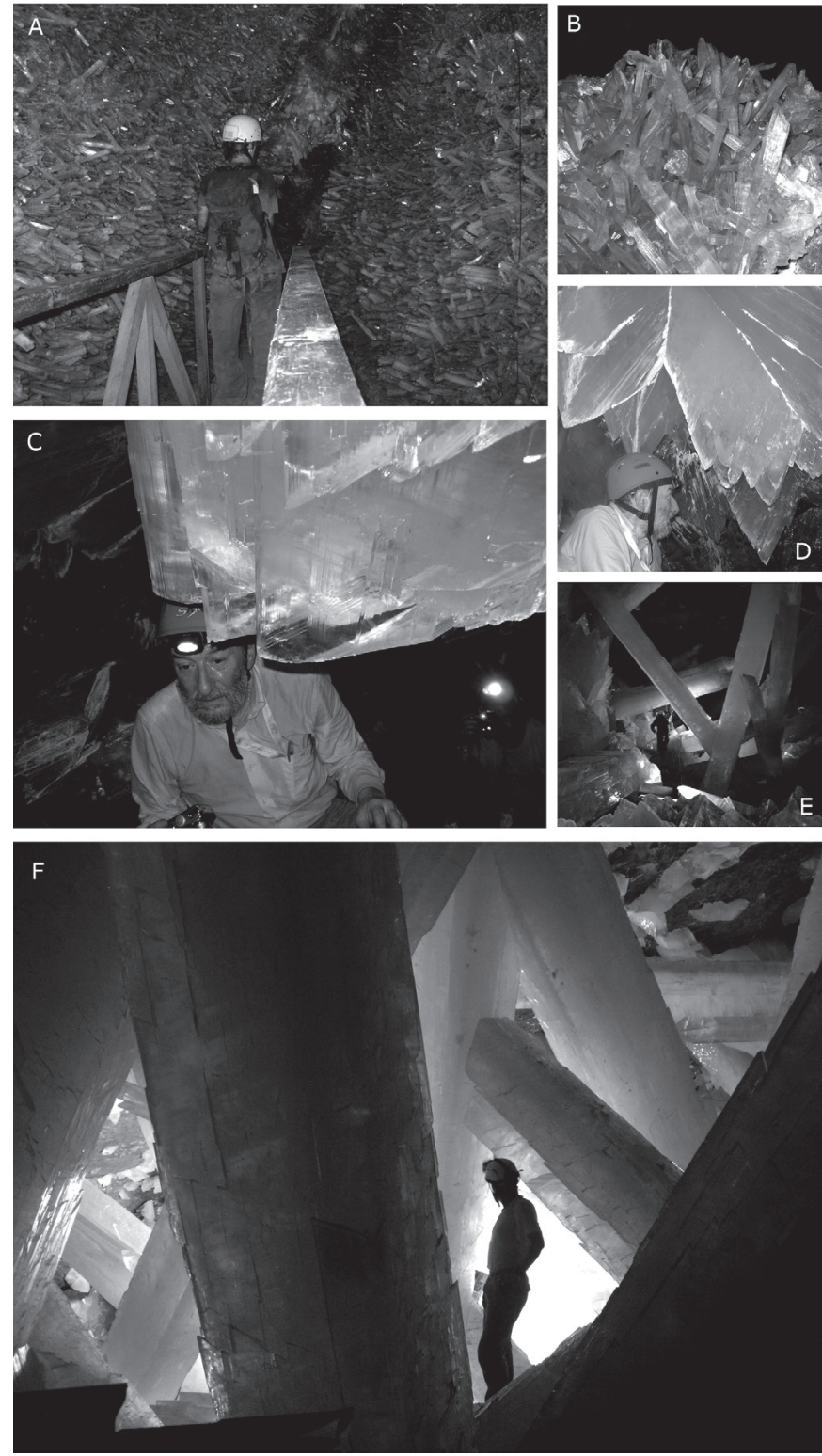

Fig. 8. The three most important caves of Naica mine: the main gallery of Cueva de las Espadas (Swords Cave) (A) at the -120 leve and a detail of its gypsum crystals (B); transparent (C) and pyramid (D) shaped selenite crystals grown in Ojo de la Reina (Queen's Cave); Cueva de los Cristales (Crystals Cave) hosts the largest known gypsum crystals of the world, in single prismatic shape $(E)(F)$ (Photo L. Sanna - Archivio La Venta \& S/F).

de la Reina (Queen's cave, at the $-290 \mathrm{~m}$ level), and Cueva de los Cristales (Crystals cave, at the $-290 \mathrm{~m}$ level).

All observed 'giant' crystal specimens of Naica caves are euhedral and are composed of gypsum, except for the subaqueous spar carbonate layered grown in Espadas cave that are covered by aragonite (Forti et al., 2009b). This sample (Figure 9A) is a smaller spar, about $6 \mathrm{~cm}$ across, covered with several $1 \mathrm{~cm}$ - thick aragonite layers (Forti, 2007). The Reina sample (Figure 9B) is composed of loosely bound lamina of completely transparent gypsum, collected at the base of a crystal wall. The Cristales sample (Figure 9C) is about $40 \mathrm{~cm}$ across consisting of a slice cut perpendicularly through a broken crystal. The dated subsample was collected close to the centre of the slice, $13 \mathrm{~cm}$ from the outer surface of the crystal.

\section{RESULTS}

According to the first analyses (Table 1), the gypsum displays low uranium concentrations and a relatively high background thorium level, but possibly within reliable age range. Ages were corrected for detrital thorium content assuming an initial ${ }^{230} \mathrm{Th} /{ }^{232} \mathrm{Th}$ ratio of 1.5 (Richards \& Dorale, 2003). We found significant differences in ages between samples. The oldest crystal is the sample from Ojo de la Reina ( $191 \pm 13 \mathrm{kyr})$ : this may approach the commencement of gypsum growth at the $-290 \mathrm{~m}$ level. The central part of a giant selenite of Cristales yielded an imprecise age in the range of $106-260 \mathrm{kyr}$. The sample was taken close to a central zone of large fluid inclusions, but if we assume that the gypsum was intact and that it grew continuously until the cave was drained. The corresponding growth rate (for $13 \mathrm{~cm}$ of accumulation) is then in the range of 0.5 to $1.22 \mathrm{~mm} / \mathrm{kyr}$, slightly less than the rate $(1.45 \mathrm{~mm} /$ kyr) previously found for the outer $50 \mathrm{~mm}$ (Lauritzen et al., 2008), and suggests that the crystal growth rate might have changed through time. The analytical results also suggest that the Uranium content of the growing gypsum has increased with time (Figure 10). The oldest samples (age > $100 \mathrm{kyr}$ ) have lowest $\mathrm{U}$ content, less than $10 \mathrm{ppb}$, samples around $10 \mathrm{kyr}$ display the highest $U$ concentrations, greater than $0.1 \mathrm{ppm}$. This trend suggests that a similar increase in the $\mathrm{U}$ content of the mother liquor (groundwater) occurred through time.

The base of the Espadas spar ( $57 \pm 1.7 \mathrm{kyr}$ ) is more recent than the crystals found in the deeper caves. The age is also in accordance with the groundwater model of the area, where a late rise in groundwater might have formed the relatively smaller and more complex crystals in the Espadas cave (Forti et al., 2009a). A subsequent aragonite layer, taken $2 \mathrm{~mm}$ above the gypsum surface dated at $15 \pm 2 \mathrm{kyr}$; a third subsample taken right beneath the surface of the speleothem and TIMS-dated yielded an age of 7.9 \pm 0.1 kyr. These ages indicate that: (1) the genesis of these minerals are related to groundwater oscillations and corresponding aeration of the cave in an epiphreatic environment and (2) the precision is apparently improved by using iron scavenging, anionic exchange chromatography and TIMS detection.

\section{CONCLUSIONS}

In this work, we have given a review of analytical problems in dissolving gypsum and the extraction of actinides from gypsum speleothems for Uraniumseries dating. We have then developed a simple dissolution method for gypsum and adapted a onestage extraction chromatography step using Eichrom TRU resin with ICP-MS determination of atomic masses. This protocol allows the dissolution of the sample and the separation of $U$ and $T h$ from a sulphate matrix in 2 working days and was successfully applied to the investigation of U-Th isotope compositions in selenite crystals from Naica caves, which have very low $\mathrm{U}$ concentration. However, iron scavenging, anionic exchange chromatography and TIMS detection gave the most precise results. 

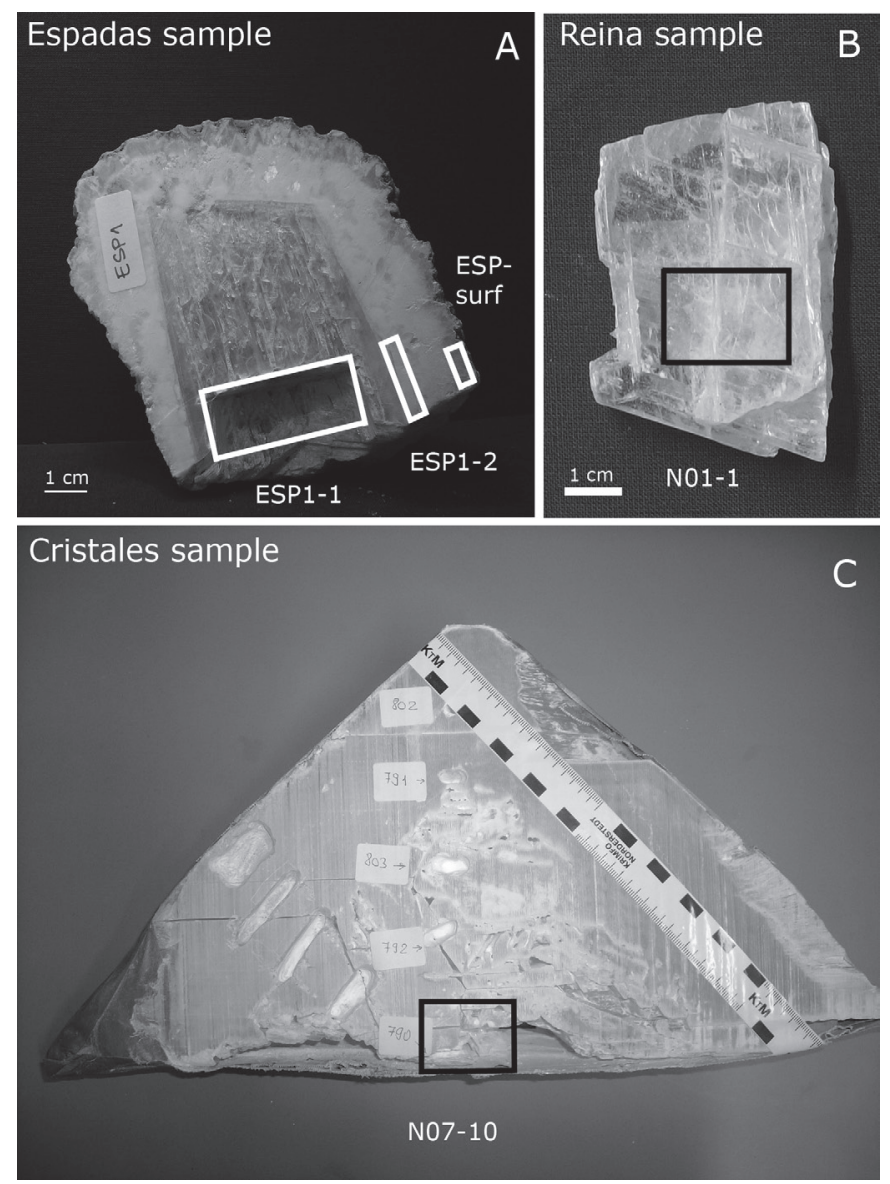

Fig. 9. Subsamples collected on Naica crystals: (A) the spar of Espadas cave is a gypsum crystal covered by aragonite; (B) a lamina of completely transparent gypsum collected at the bottom of a crystal wall in the entrance of Ojo de la Reina; (C) a slice cut perpendicularly through a broken giant selenite crystal of Cristales. Scale in centimeters.

\section{APPENDIX (EXPERIMENTAL) Recommended chemical procedures}

All operations were performed in an overpressured cleanlab or in an overpressured LAF-bench with laminar airflow. All containers were of Teflon, pre-cleaned by boiling in $7 \mathrm{M}$ $\mathrm{HNO}_{3}$ and rinsed in milliQ water. $\mathrm{FeCl}_{3}$, for the scavenging alternative, was cleaned by extraction into di-isopropyl ether (DPE) from 9M $\mathrm{HCl}$ and back-extraction into $0.1 \mathrm{M} \mathrm{HCl}$; residual $\mathrm{DPE}$ was boiled off. Columns were made from disposable polyethylene Pasteur pipettes with a polyethylene frit (porous, sintered material) inserted. Solutions were evaporated on a hotplate in Teflon containers with doubly perforated evaporation closures $\left(\right.$ Savillex $\left.{ }^{\mathbb{R}}\right)$, through which filtered air was drawn via a manifold directly into a water pump outside the cabinet. Vapour and fumes $\left(\mathrm{HNO}_{3}, \mathrm{HCl}\right.$, $\mathrm{HF}, \mathrm{HClO}_{4}$ ) were then directly absorbed in large amounts of water in a safe manner. In this way, no acid fumes entered the workspace.

All reagents were either of Suprapur ${ }^{\circledR}$ (Merck) (i.e. $\mathrm{HBr}$ and $\mathrm{HClO}_{4}$ ) or double (sub-boiling) distilled in our laboratory $\left(\mathrm{HNO}_{3}, \mathrm{HCl}, \mathrm{HF}\right)$.

\section{Sample preparation}

Subsamples should be cut with pre-cleaned (acid, water, alcohol) tools; we use a dentist's drill with cutting disks to extract subsamples in one piece or as coarse chips. These coarse pieces were then crushed in a mortar to desired grain size. This procedure minimizes contamination from tools and optimizes grain size (powder) to enhance dissolution.

\section{Age, kyr}

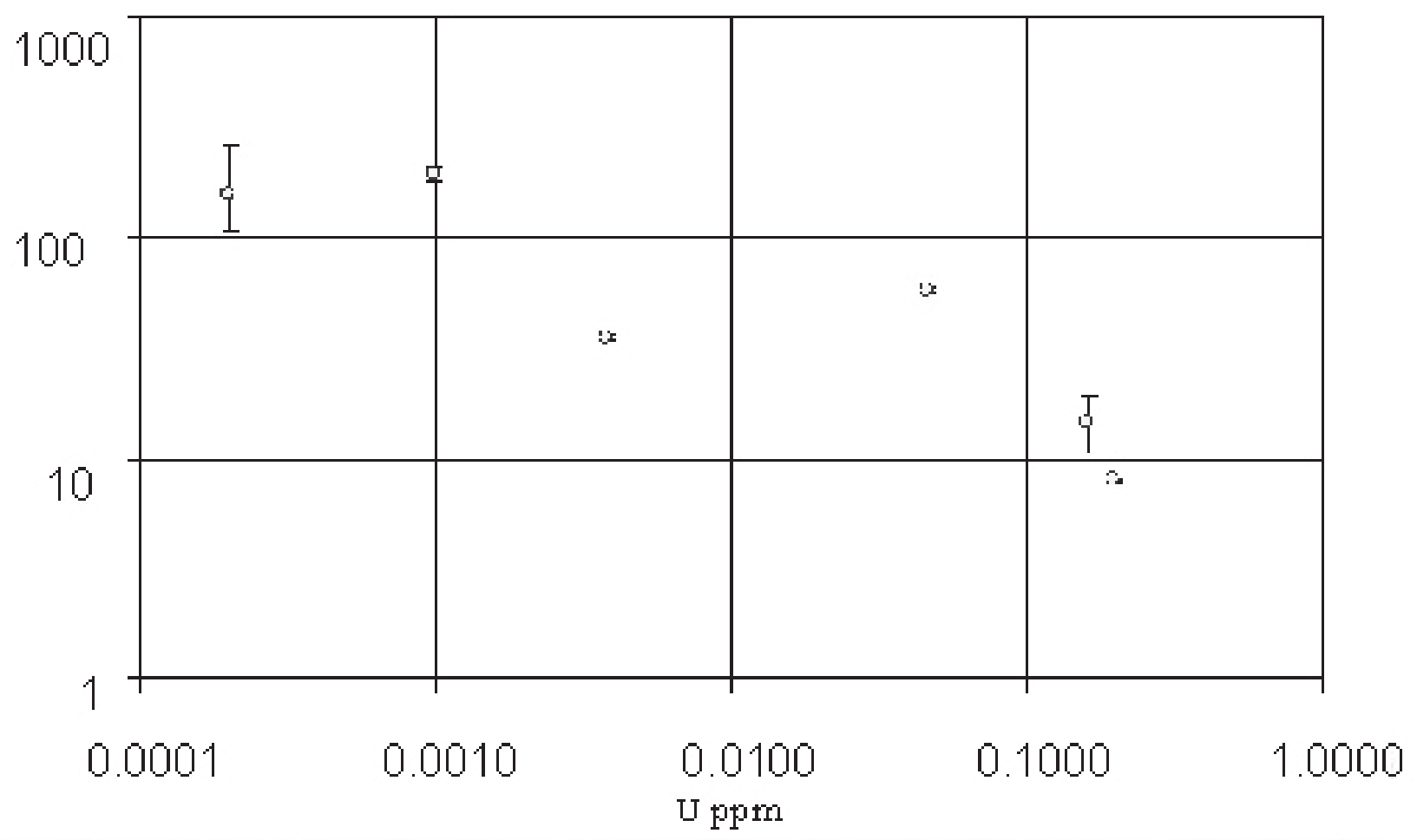

Fig. 10. Age and analytical error as a function of $U$ content of the Naica gypsum crystals. Data from Table 1. Samples older than 100 kyr have very low $\mathrm{U}$ concentrations (<10 ppb), whilst the younger samples (ca $10 \mathrm{kyr}$ ) display much higher concentrations $(>0.1 \mathrm{ppm}$ ). 


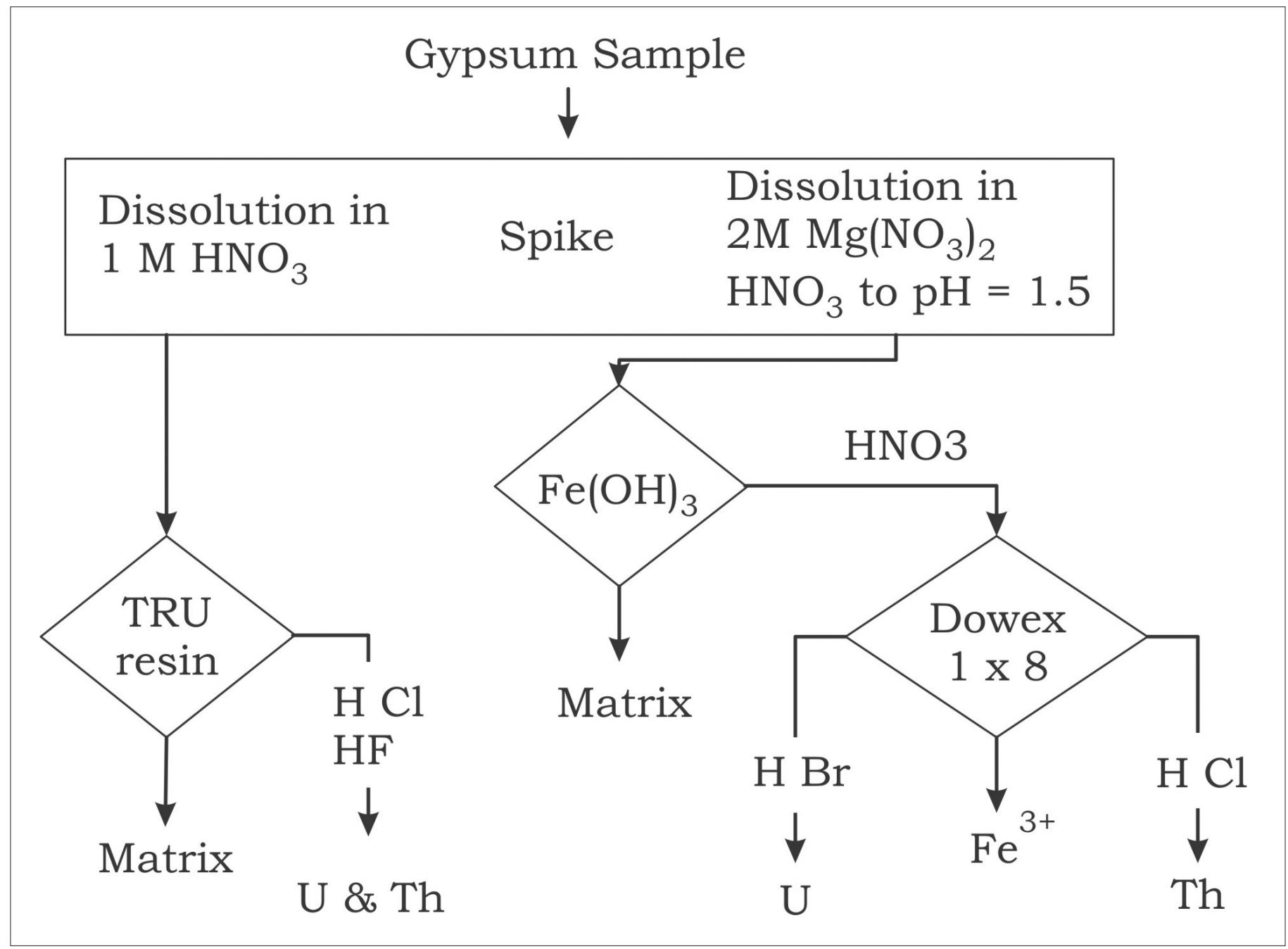

Fig. 11. Flow-chart of the analytical procedures. Left: direct retention by TRU resin (procedure a). Right: iron scavenger approach with anion exchange chromatography (procedure b).

\section{Sample dissolution}

Figure 11 depicts the flowchart of our recommended preparation alternatives. In both cases, the finely powdered sample is brought into solution by means of either $1 \mathrm{M} \mathrm{HNO}_{3}$ or in $2 \mathrm{M} \mathrm{Mg}\left(\mathrm{NO}_{3}\right)_{2} / \mathrm{HNO}_{3}$ at $\mathrm{pH}$ 1.5. The solution is spiked and equilibrated overnight before further treatment.

Extraction Chromatography (EXC) was performed using TRU-resin ${ }^{\mathrm{TM}}$ (Triskem), a non-ionic acrylicester polymer comprising a combination of trin-butylphosphate (TBP) and octyl(phenyl)-N,Ndiisobutylcarbamoylmethyl hosphine oxide (CMPO) supported on an inert substrate (Amberlite XAD-7). This resin has a high affinity to tri-, tetra- and hexavalent actinides, extracted as their nitrate complexes (Peterson et al., 2007). Anionic exchange of $U$ and $T h$ was done on Biorad (Dowex) AG 1x8 (200 - 400 mesh) resin, consisting of quaternary ammonium $\left(-\mathrm{NR}_{3}{ }^{+}\right)$ groups, capable of binding nitrate- and chloride complexes of $\mathrm{UO}_{2}{ }^{2+}$ (e.g. $\mathrm{UO}_{2} \mathrm{Cl}_{4}{ }^{2-}$ ) and the nitrate complex of $\mathrm{Th}^{4+}$ in strong $\mathrm{HCl}$ or $\mathrm{HNO}_{3}$, respectively. The complexes can be broken by more dilute $\mathrm{HCl}$ and $\mathrm{HBr}$ eluants. The nitrate medium is also capable of separating $\mathrm{UO}_{2}{ }^{2+}$ and $\mathrm{Th}^{4+}$ from $\mathrm{Fe}^{3+}$ in $\mathrm{HNO}_{3}$.

\section{Direct retention on TRU resin.}

The clear, centrifuged sample is slowly passed through a column prepared with TRU resin, previously cleaned by several $c v$ (column void volume, it is approximately half of the resin volume) $0.1 \mathrm{M} \mathrm{HCl}+0.2 \mathrm{M} \mathrm{HF}$ and conditioned with $4 \mathrm{cv}$ $1 \mathrm{M} \mathrm{HNO}_{3}$. The column $(7.2 \times 150 \mathrm{~mm})$ contains 1 $\mathrm{mL}(240 \mathrm{mg})$ of Eichrom TRU resin, 100-150 $\mathrm{mm}$ particle size, suspended in a few $\mathrm{mL}$ of water. After application of the sample, the column was washed with $4 \mathrm{cv}$ of $1 \mathrm{M} \mathrm{HNO}_{3}$ in small portions. Then, $\mathrm{HNO}_{3}$ was replaced by $2 \mathrm{cv}$ of $1 \mathrm{M} \mathrm{HCl}$, after which $\mathrm{U}$ and Th were eluted with $14 c v(7 \mathrm{~mL})$ of $0.1 \mathrm{M} \mathrm{HCl}-0.2 \mathrm{M}$ HF. To the eluates were added 1 drop concentrated $\mathrm{HNO}_{3}$. They were evaporated to complete dryness in Teflon vials. Organics can be removed by adding one drop conc. $\mathrm{HClO}_{4}$ in the $\mathrm{HNO}_{3}$ evaporation step, followed by a second $\mathrm{HNO}_{3}$ treatment. If the procedure is done correctly, the residue is hardly perceptible.

\section{Scavenging and separation of $U$ and Th}

During dissolution and spiking, 2 drops of $\mathrm{FeCl}_{3}$ are added to the solution, corresponding to 100 - $200 \mathrm{mg} \mathrm{Fe}$. After centrifugation, the solution is neutralised with conc. $\mathrm{NH}_{3}$, using the brown colour of $\mathrm{Fe}(\mathrm{OH})_{3}$ as an indicator, plus an excess 
of $1 \mathrm{~mL}$ per $100 \mathrm{~mL}$ solution. The final solution will smell of ammonia. After flocculation, $\mathrm{Fe}(\mathrm{OH})_{3}$ is centrifuged off and washed with $5-10 \mathrm{~mL}$ water containing one drop diluted ammonia solution. After centrifugation, the precipitate is dried down several times with conc. $\mathrm{HNO}_{3}$ and finally dissolved in $0.5 \mathrm{~mL} 7.5 \mathrm{M} \mathrm{HNO}_{3}$. Iron is eluted from a $1 \mathrm{~mL}$ AG $1 \times 8$ resin column with a total of $3-$ $4 \mathrm{cv} 7.5 \mathrm{MHNO}_{3}$. (The column is pre-cleaned and conditioned with $6 \mathrm{M} \mathrm{HCl}$, followed by $8 \mathrm{cv}$ water and conditioned with $4 \mathrm{cv} 7.5 \mathrm{M} \mathrm{HNO}$ ). Th is then eluted with $6 \mathrm{cv} 6 \mathrm{M} \mathrm{HCl}$, whereafter $\mathrm{U}$ is eluted with $6 \mathrm{cv} 1 \mathrm{M} \mathrm{HBr}$. A second purification step on each fraction is done on $0.25 \mathrm{~mL}$ columns with AG $1 \times 8$ resin, using the same procedure. Finally, the fractions are evaporated to dryness with one drop concentrated $\mathrm{HNO}_{3}$.

\section{ACKNOWLEDGEMENTS.}

This work is a part of the international collaboration project "Paleogyp" (CG 1707, Ministery of Science and Innovation, Spain), lead by J-M. Calaforra. We also thank The Naica Project by La Venta Exploring Team, Speleoresearch \& Films in Mexico City and the Peñoles Company for allowing access to the Naica Mine and for their support during the field work. Laboratory fascilities were provided by The Department of Earth Sciences, Bergen. Prof. Tom Andersen of the Department of Geoscience at The University of Oslo is thanked for supporting our ICP-MS work. Dr. Yuval Rohnen helped in numerous practical aspects of the laboratory work. Drs. Joyce Lundberg, Russell Drysdale and an anonymous referee made constructive suggestions that improved the paper.

\section{REFERENCES}

Bock R., 1979 - A handbook of decomposition methods in analytical chemistry (Aufschlussmethoden der anorganischen und organischen Chemie). International Textbook Co., Glasgow, 444 p.

Calaforra J.M., 1998 - Karstologia de yesos [Gypsum Karstology]. Universidad de Almeria, Servicio de Publicationes Instituto de Estudios Almerienses, Almeria, $384 \mathrm{p}$.

Calaforra J.M. \& Forti P., 1994 - Two new types of gypsum speleothems from new mexico: gypsum trays and gypsum dust. National Speleological Society Bulletin, 56(1): 32-37.

Davis D.G., 2000 - Extraordinary features of Lechuguilla Cave, Guadulupe Mountains, New Mexico. Journal of Cave and Karst Studies, 62(2): 147-157.

Dillon J. R., 2009 - Dating of Quaternary eruption events using U-series ages of lava cave gypsum crusts. Geological Society of America, Annual meeting (18- 21 october 2009). Abstracts with programs, 41(7): 193.

Doran L.M. \& Hill C.A., 1998 - Gypsum trays in Torgac cave, New Mexico. Journal of Cave and Karst Studies, 60(1): 3943.

Ford D.C. \& Williams P.W., 2007 - Karst Hydrogeology and Geomorphology. John Wiley \& Sons, Chichester, U.K., $562 \mathrm{p}$.
Forti P., 2007 - Studio della struttura interna di una stalagmite della Grotta delle Spade (Naica, Messico). [Study of the internal structure of a stalagmite of the Swords Cave (Naica, Mexico)]. Grotte e Dintorni, 6(13): 3- 20.

Forti P., Galli E. \& Rossi A., 2009a - Le grotte di Naica: non solo giganteschi cristalli di gesso. [The caves of Naica: not only giant gypsum crystals]. Rivista Italiana di Mineralogia, 3-2009: 180-196.

Forti P., Galli E. \& Rossi A., 2009b - Minerogenesis in the Naica caves (Chihuahua, Mexico). Proceeding of 15th International Congress of Speleology, Kerrville $\mathrm{Tx}$, USA, $300-305$.

Forti P. \& Rossi A., 2003 - Il carsismo ipogeo nei gessi italiani. [The ipogean karst in the Italian gypsums]. In: Forti P. (Ed.) - Le aree carsiche gessose d'Italia. Memorie Istituto Italiano di Speleologia, Serie II, vol XIV: 65- 87.

Foshag W., 1927 - The selenite caves of Naica, Mexico. American Mineralogist, 12: 252- 232.

Gascoyne M., 1980 - Pleistocene climates determined from stable isotope and geochronologic studies of speleothem. Ph. D. Thesis Dissertation. McMaster University, Hamilton Ontario: 467 p.

Hellstrom J., 2003 - Rapid and accurate U/Th dating using parallel ioncounting multicollector ICP-MS. Jounal of Analytical Atomic Spectrometry, 18: 1346-1351.

Ivanovich M. \& Harmon R.S., 1982 - Uranium Series Disequilibrium. Applications to environmental problems. Clarendon, Oxford, $571 \mathrm{p}$.

Klimchouk A., 2000 - Dissolution and conversions of gypsum and anhydrite. In: Klimchouk A., Ford D.C., Palmer A.N. \& Dreybrodt D. (Ed.) - Speleogenesis. Evolution of karst aquifers. National Speleogical Society, Huntsville, Ala. USA: 160-168

Klimchouk A., Lowe D.J., Cooper A. \& Sauro U. (Eds.), 1997 - Gypsum Karst of the World. International Journal of Speleology, 25(3-4), 1996: 308 p.

Korshunov V. \& Shavrina E.V., 1998 - Gypsum speleothems of freezing origin. Journal of Cave and Karst Studies, 60(3): 146-150.

Lauritzen S.E., 2002 - Marble Stripe karst of the Scandinavian Caledonides: An end-member in the contact karst spectrum. Acta Carsologica, 30(2): 47-79.

Lauritzen S.E., Constantin S. \& Forti P., 2008 Chronology and growth rate of the Naica giant gypsum crystals. International Geological Congress Oslo 2008, Oslo:http://www.cprm.gov.br/33IGC/1322921.html

Lauritzen, S.E. and Lundberg, J., 1997. TIMS Age4U2U A program for raw data processing, error propagation and ${ }^{230} \mathrm{Th} /{ }^{234} \mathrm{U}$ age calculation for mass spectrometry. Turbo Pascal Code. Department of Geology, Bergen University.

Lauritzen \& Lundberg J., 1999 - Calibration of the speleothem delta function: an absolute temperature record for the Holocene in northern Norway. Holocene, 9: 659-669.

Maltsev V., 1997 - A model of structure and genesis for the gypsum 'nest' found in the Geophysicheskaya cave (Kugiangtou Mountains, Turkmenistan). Unknown.

Novozamsky I., Van Der Lee H. \& Houba V.J.G., 1995 - Sample Digestion Procedures for Trace Element Determination. Microchimica Acta, 119: 183-189. 
Onac P.B. \& Lauritzen S.E., 1995 - On some cave minerals from Northern Norway. International Journal of Speleology, 24: 67-75.

Peterson D.S., Plionis A.A. \& Gonzalez E.R., 2007 Optimization of extraction chromatography separations of trace levels of actinides with ICP-MS detection. Journal of Separation Science, 30: 1575- 1582.

Przbylowicz W., Schwarcz H.P. \& Latham A.G., 1991 - Dirty calcites 2: Uranium-series dating of artificial calcite-detritus mixtures. Chemical Geology, 86: 161178.

Richards D.A. \& Dorale J.A., 2003 - U-series chronology and environmental applications of speleothems. In:
Bourdon B., Henderson G.M., Ludstrom C. \& Turner S. (Ed.) - Uranium-series Geochemistry. Reviews in Mineralogy and Geochemistry, 52: 407460.

Schwarcz H.P., 1980 - Absolute age determinations of archaeological sites by uranium dating of travertines. Archaeometry, 22: 3-24.

Schwarcz H.P. \& Latham A.G., 1989 - Dirty calcites I: Uranium series dating of contaminated calcite using leachates alone. Isotope Geoscience, 80: 35-43.

Yang L., 2009 - Accurate and precise determination of isotopic ratios by MC-ICP-MS: A Review. Mass Spectrometry Reviews, 28: 990-1011. 